\title{
Mycobacterium elephantis sp. nov., a rapidly growing non-chromogenic Mycobacterium isolated from an elephant
}

\author{
Hasan Shojaei, ${ }^{1}$ John G. Magee, ${ }^{2}$ Roger Freeman, ${ }^{2}$ Malcolm Yates, ${ }^{3}$ \\ Neil U. Horadagoda ${ }^{4}$ and Michael Goodfellow ${ }^{1}$
}

Author for correspondence: Michael Goodfellow. Tel: +44 191222 7706. Fax: +44 1912225228. e-mail:m.goodfellow@ncl.ac.uk

\author{
1 Department of \\ Agricultural and \\ Environmental Science, \\ University of Newcastle, \\ Newcastle upon Tyne \\ NE1 7RU, UK \\ 2 Regional Centre for \\ Mycobacteriology, Public \\ Health Laboratory, General \\ Hospital, Newcastle upon \\ Tyne NE4 6BE, UK \\ 3 Public Health Laboratory, \\ Dulwich Hospital, Dulwich, \\ London SE22 8QF \\ 4 Department of Veterinary \\ Paraclinical Studies, Faculty \\ of Veterinary Medicine \\ and Clinical Science, \\ University of Perodeniya, \\ Sri Lanka
}

\begin{abstract}
A strain isolated from a lung abscess in an elephant that died from chronic respiratory disease was found to have properties consistent with its classification in the genus Mycobacterium. An almost complete sequence of the 165 rDNA of the strain was determined following the cloning and sequencing of the amplified gene. The sequence was aligned with those available on mycobacteria and phylogenetic trees inferred by using three treemaking algorithms. The organism, which formed a distinct phyletic line within the evolutionary radiation occupied by rapidly growing mycobacteria, was readily distinguished from members of validly described species of rapidly growing mycobacteria on the basis of its mycolic acid pattern and by a number of other phenotypic features, notably its ability to grow at higher temperatures. The type strain is Mycobacterium elephantis DSM 44368'.
\end{abstract}

Keywords: Mycobacterium elephantis sp. nov., polyphasic taxonomy, lung abscess of adult elephant

\section{INTRODUCTION}

A rapidly growing, weakly acid-alcohol-fast organism isolated from a lung abscess of an elephant had properties consistent with its classification in the genus Mycobacterium (Lévy-Frébault \& Portaels, 1992; Goodfellow \& Magee, 1997). In the present investigation, the organism was examined for a selection of genotypic and phenotypic properties to clarify its taxonomic position. It is apparent from the results that the organism represents a new species, for which the name Mycobacterium elephantis is proposed.

\section{METHODS}

Organism and growth conditions. The organism (strain $484^{\mathrm{T}}$ ) was isolated on Löwenstein-Jensen medium after $7 \mathrm{~d}$ incubation at $37^{\circ} \mathrm{C}$. It was then cultivated on the same medium at $25,36,42$ and $45^{\circ} \mathrm{C}$ and on Columbia blood, MacConkey, Middlebrook $7 \mathrm{H} 10$ and $5 \%(\mathrm{w} / \mathrm{v})$ sodium chloride agars at 25 and $36{ }^{\circ} \mathrm{C}$ for between 3 and $10 \mathrm{~d}$. The strain was maintained on Middlebrook $7 \mathrm{H} 10$ agar and grown at $36{ }^{\circ} \mathrm{C}$ for the remaining phenotypic tests.

The EMBL accession number for the $16 \mathrm{~S}$ rDNA sequence of strain $484^{\top}$ is AJ010747.
Phenotypic characterization. Standard methods were used throughout. The Gram and Ziehl-Neelsen stains were carried out on cells grown for $5 \mathrm{~d}$ on Middlebrook $7 \mathrm{H} 10$ agar. Catalase activity, niacin activity and nitrate reduction were determined after $10 \mathrm{~d}$, aryl sulphatase production after 3 and $14 \mathrm{~d}$, tellurite reduction after $5 \mathrm{~d}$, Tween hydrolysis after $10 \mathrm{~d}$ and urease production after $3 \mathrm{~d}$. Antibioticsusceptibility studies were carried out using the resistance ratio method.

Extraction and analysis of mycolic acids. Lyophilized biomass from 10-d-old Middlebrook 7H10 agar plates was degraded by alkaline methanolysis (Saddler et al., 1987) and twodimensional TLC of the methanolysates was carried out according to the method of Minnikin et al. (1980).

16S rDNA sequencing. The test strain was shaken in $100 \mathrm{ml}$ Sauton's broth (Mordarska et al., 1972) at 150 r.p.m. for $14 \mathrm{~d}$ at $36^{\circ} \mathrm{C}$. The biomass was harvested by centrifugation at 10000 r.p.m. for $10 \mathrm{~min}$ and washed twice in sterile TE buffer (Tris/HCl, pH 8, 10 mM; EDTA $1 \mathrm{mM}$ ); approximately $100 \mathrm{mg}$ wet weight biomass was used for DNA extraction. The extraction and purification of DNA and the amplification, cloning and sequencing of the 16S rRNA gene were carried out as described previously (Chun \& Goodfellow, 1995; Shojaei et al., 1997). The 16S rDNA sequence of strain $484^{\mathrm{T}}$ was aligned manually with all available sequences of rapidly growing mycobacteria by using the AL16s program (Chun, 1995). The additional sequence data were obtained from the GenBank and EMBL databases. 


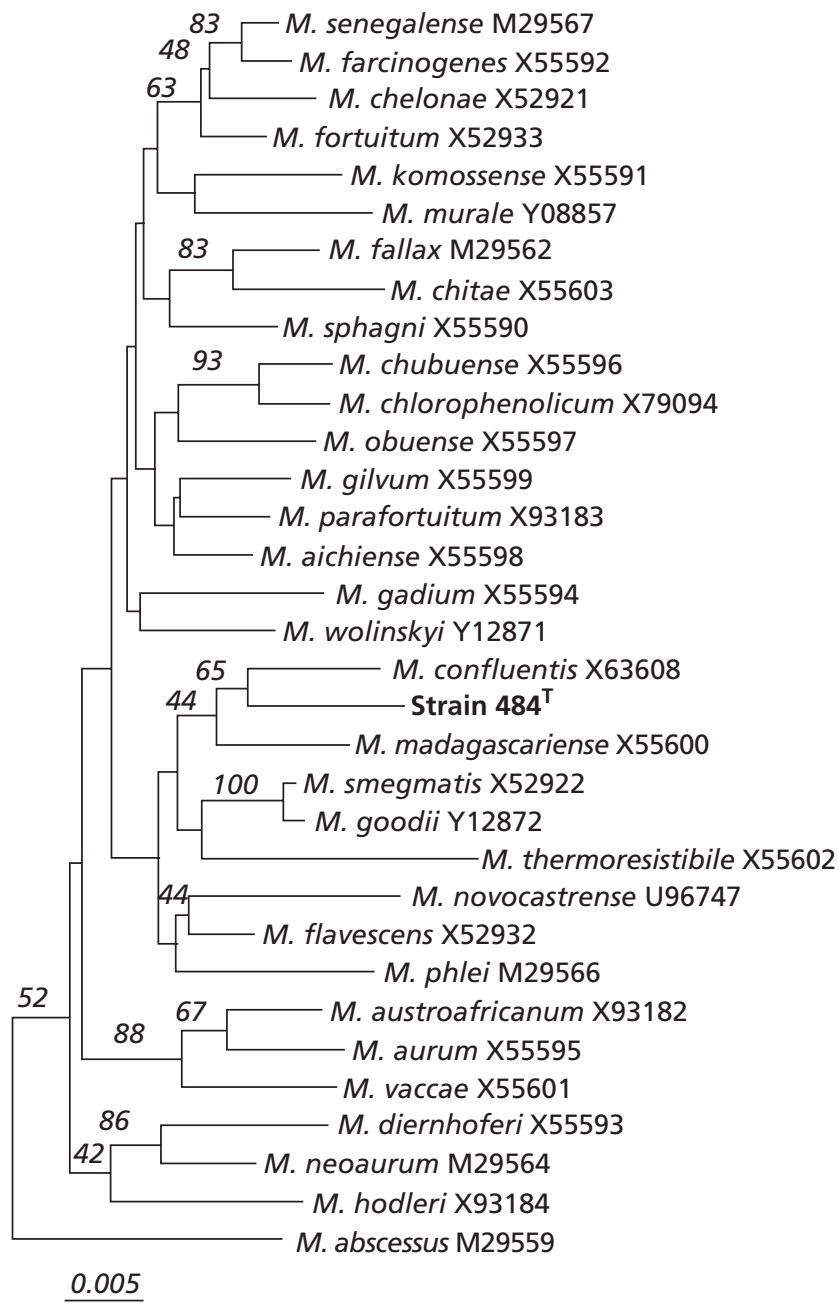

Fig. 1. Neighbour-joining tree (Saitou \& Nei, 1987) based on nearly complete $16 \mathrm{~S}$ rDNA sequences of rapidly growing mycobacteria (1446 nucleotides) showing the phylogenetic position of strain $484^{\top}$. The sequence of the type strain of Mycobacterium hassiacum was not included in this analysis as the phylogenetic position of this rapidly growing organism is with the slowly growing mycobacteria (Schröder et al., 1997). The numbers at the nodes indicate the level of bootstrap support, based on a neighbour-joining analysis of 1000 resampled datasets; only values greater than $40 \%$ are given. Bar, 0.005 substitutions per nucleotide position.

Evolutionary trees were inferred by using three algorithms, namely the Fitch-Margoliash (1967), maximum-parsimony
(Kluge \& Farris, 1969) and neighbour-joining (Saitou \& Nei, 1987) methods. Evolutionary distance matrices for the Fitch-Margoliash and neighbour-joining methods were generated as described by Jukes \& Cantor (1969). The PHYLIP package (Felsenstein, 1993) was used for all of the analyses. The resultant unrooted tree topologies were evaluated by performing bootstrap analyses (Felsenstein, 1985) of the neighbour-joining database on 1000 resamplings with the SEQBOOT and CONSENSE programs in the PHYLIP package. The root positions of the unrooted tree based on the neighbour-joining method was estimated by using three outgroup organisms, namely Gordona terrae DSM $43249^{\mathrm{T}}$ (sequence accession no. X79286), Nocardia asteroides ATCC $19247^{\mathrm{T}}$ (Z36934) and Rhodococcus equi DSM 20307 (X80614), as described by Swofford \& Olsen (1990).

\section{RESULTS AND DISCUSSION}

An almost complete 16S rDNA sequence (1517 nucleotides) was obtained for strain $484^{\mathrm{T}}$. Comparison of this nucleotide sequence with available sequences for representatives of the genus Mycobacterium showed that the organism fell within the evolutionary radiation occupied by rapidly growing mycobacteria (Fig. 1). The pairwise nucleotide similarity value found between strain $484^{\mathrm{T}}$ and the rapidly growing mycobacteria ranged from 95.6 to $97.7 \%$, giving a mean of $96 \cdot 7 \pm 0.5 \%$. The corresponding mean nucleotide similarity value found between strain $484^{\mathrm{T}}$ and the representative slowly growing mycobacteria was $96 \cdot 2 \pm 0 \cdot 4 \%$.

The nucleotide sequence of strain $484^{\mathrm{T}}$ shows substantial differences from the corresponding sequences of its nearest neighbours, namely Mycobacterium confluentis $(97 \cdot 8 \%)$, Mycobacterium madagascariense $(97.6 \%)$ and Mycobacterium phlei $(97.7 \%)$; these values correspond to 29,33 and 30 nucleotide differences, respectively. Comparable scales of difference exist between the nucleotide sequences of validly described species of rapidly growing mycobacteria (Shojaei et al., 1997). The positions of the test and marker strains in the phylogenetic tree were not markedly affected by either the tree-making algorithms or the outgroup strains (Fig. 1). It is also clear from Fig. 1 that the relationship between strain $484^{\mathrm{T}}$ and its nearest neighbour is not supported by high bootstrap values. However, the sequence of this strain, like those of other rapidly growing mycobacteria, has the charac-

Table 1. Characteristics that differentiate strain $484^{\top}$ from related mycobacteria

\begin{tabular}{|c|c|c|c|c|c|}
\hline Strain/species & $\begin{array}{l}\text { Growth at } \\
45^{\circ} \mathrm{C}\end{array}$ & $\begin{array}{l}\text { Nitrate } \\
\text { reduction }\end{array}$ & $\begin{array}{l}\text { Aryl sulphatase } \\
\text { (14 d) }\end{array}$ & $\begin{array}{l}\text { Growth on } 5 \% \\
(w / v) ~ N a C l \text { agar }\end{array}$ & Pigmentation \\
\hline Strain 484T & + & + & - & - & $\mathrm{n}$ \\
\hline M. confluentis & - & - & + & - & $\mathrm{n}$ \\
\hline M. madagascariense & - & - & - & - & s \\
\hline M. phlei & + & + & + & + & $\mathrm{s}$ \\
\hline
\end{tabular}

n, Non-chromogenic; s, scotochromogenic. 
teristic short helix at positions 451-482 (Escherichia coli numbering system; Brosius et al., 1978).

The phenotypic properties of strain $484^{\mathrm{T}}$ are also consistent with its classification in the genus $\mathrm{Myco-}$ bacterium (Lévy-Frébault \& Portaels, 1992). The organism is aerobic, non-motile, Gram-positive and weakly acid-alcohol-fast. It is catalase- and ureasepositive, reduces nitrate and is positive for Tween hydrolysis. Older cultures may show weak chromogenicity. The detection of $\alpha$ - and keto-mycolates and wax esters in methanolysates of the strain distinguishes it from the rapidly growing mycobacteria $\mathrm{Myco-}$ bacterium abscessus, Mycobacterium chelonae, M. confluentis and Mycobacterium fortuitum, but not from $M$. madagascariense or $M$. phlei. However, these species are scotochromogenic and can be distinguished from strain $484^{\mathrm{T}}$ by the phenotypic characteristics shown in Table 1.

It is evident from the chemical, $16 \mathrm{~S}$ rDNA sequencing and microbiological data that strain $484^{\mathrm{T}}$ shows a combination of properties that distinguish it from all other validly described species of Mycobacterium. It is proposed, therefore, that this organism be classified in the genus Mycobacterium as Mycobacterium elephantis.

\section{Description of Mycobacterium elephantis sp. nov.}

Mycobacterium elephantis (e.le.phan'tis. L. n. elephas elephant; L. gen. n. elephantis of the elephant).

Aerobic, Gram-positive, weakly acid-alcohol-fast, asporogenous, non-motile organism which is nonchromogenic. Cells are cocco-bacillary and 1.2-1.4 $\mu \mathrm{m}$ long. The organism is positive for catalase $(45 \mathrm{~mm}$ foam), nitrate reductase, Tween hydrolysis and urease. Negative for tellurite reduction (5 d) and aryl sulphatase activity (14 d). Good growth occurs at 25, 37, 42 and $45^{\circ} \mathrm{C}$. Growth is inhibited by isoniazid $\left(1.4 \mathrm{mg}^{-1}\right)$, rifampicin $\left(16 \mathrm{mg}^{-1}\right)$, pyrazinamide (66 $\left.\mathrm{mg}^{-1}\right)$, thiacetazone $\left(10 \mathrm{mg}^{-1}\right)$ and thiophen-2caboxylic acid hydrazide, but not by ciprofloxacin $\left(2 \cdot 5 \mathrm{mg} \mathrm{1}^{-1}\right)$ or ethambutol $\left(3 \cdot 2 \mathrm{mg} \mathrm{l}^{-1}\right)$. Isolated from a lung abscess of an adult elephant that had died from chronic respiratory disease. The type strain of $M$. elephantis is strain $484^{\mathrm{T}}\left(=\mathrm{DSM} 44368^{\mathrm{T}}\right)$.

\section{ACKNOWLEDGEMENTS}

H.S. is grateful to the Iranian Government for receipt of a studentship.

\section{REFERENCES}

Brosius, J., Palmer, M. L., Kennedy, P. J. \& Nobler, H. F. (1978). Complete nucleotide sequence of a $16 \mathrm{~S}$ ribosomal RNA gene from Escherichia coli, Proc Natl Acad Sci USA 75, 4801-4805. Chun, J. (1995). Computer-assisted classification and identification of actinomycetes. PhD thesis, University of Newcastle.

Chun, J. \& Goodfellow, M. (1995). A phylogenetic analysis of the genus Nocardia with 16S rRNA gene sequences, Int $J$ Syst Bacteriol 45, 240-245.

Felsenstein, J. (1985). Confidence limits on phylogenies: an approach using the bootstrap, Evolution 39, 783-791.

Felsenstein, J. (1993). PHYLIP (phylogenetic inference package), version 3.51c. Department of Genetics, University of Washington, Seattle, USA.

Fitch, W. M. \& Margoliash, E. (1967). Construction of phylogenetic trees; a method based on mutation distances as estimated by cytochrome $c$ sequences is of general applicability, Science 155, 279-284.

Goodfellow, M. \& Magee, J. G. (1997). Taxonomy of mycobacteria. In Mycobacteria, vol. 1. Basic Aspects, pp. 1-71. Edited by P. Gangadharam \& P. A. Jenkins. New York: Chapman \& Hall.

Jukes, T. H. \& Cantor, C. R. (1969). Evolution of protein molecules. In Mammalian Protein Metabolism, vol. 3, pp. 21-132. Edited by H. N. Munro. New York: Academic Press.

Kluge, A. G. \& Farris, F. S. (1969). Quantitative phyletics and the evolution of anurans, Syst Zool 18, 1-32.

Lévy-Frébault, V. V. \& Portaels, F. (1992). Proposed minimal standards for the genus Mycobacterium and for description of new slowly growing Mycobacterium species, Int $J$ Syst Bacteriol 42, 315-323.

Minnikin, D. E., Hutchinson, I. G., Caldicott, A. B. \& Goodfellow, M. (1980). Thin-layer chromatography of methanolysates of mycolic acid containing bacteria, J Chromatogr 188, 221-233.

Mordarska, H., Mordarski, M. \& Goodfellow, M. (1972). Chemotaxonomic characters and classification of some nocardioform bacteria, J Gen Microbiol 71, 77-86.

Saddler, G. S., O’Donnell, A. G., Goodfellow, M. \& Minnikin, D. E. (1987). SIMCA pattern recognition in the analysis of streptomycete fatty acids, J Gen Microbiol 133, 1337-1347.

Saitou, N. \& Nei, M. (1987). The neighbor-joining method: a new method for reconstructing phylogenetic trees, Mol Biol Evol 4, 406-425.

Schröder, K. H., Neumann, L., Kroppenstedt, R. M. \& Reischl, U. (1997). Mycobacterium hassiacum sp. nov., a new rapidly growing thermophilic Mycobacterium, Int J Syst Bacteriol 47, 86-91.

Shojaei, H., Goodfellow, M., Magee, J. G., Freeman, R., Gould, F. K. \& Brignall, C. G. (1997). Mycobacterium novocastrense sp. nov., a rapidly growing photochromogenic Mycobacterium, Int J Syst Bacteriol 47, 1205-1207.

Swofford, D. L. \& Olsen, G. J. (1990). Phylogenetic reconstruction. In Molecular Systematics, pp. 411-501. Edited by D. Hillis \& C. Moritz. Sunderland, MA: Sinauer. 